International African Library 16

General Editors: J. D. Y. Peel and David Parkin

\title{
POETRY, PROSE AND POPULAR CULTURE IN HAUSA
}




\title{
International African Library
}

\author{
General Editors
}

\author{
J. D. Y. Peel and David Parkin
}

The International African Library is a major monograph series from the International African Institute and complements its quarterly periodical $A$ frica, the premier journal in the field of African studies. Theoreticallv informed ethnographies, studies of social relations 'on the ground' which are sensitive to local cultural forms, have long been central to the Institute's publications programme. The $I A L$ maintains this strength but extends it into new areas of contemporary concern, both practical and intellectual. It includes works focused on problems of development, especially on the linkages between the local and national levels of society; studies along the interface between the social and environmental sciences; and historical studies, especially those of a social, cultural or interdisciplinary character.

Titles in the series:

5 Gunther Schlee Identities on the move: clanship and pastoralism in northern Kenya

7 Karin Barber I could speak until tomorrow: oriki, women and the past in a Yoruba town (Published in the USA by the Smithsonian Institution Press and in Nigeria by Ibadan University Press)

8 Richard Fardon Between God, the dead and the wild: Chamba interpretations of religion and ritual (Published in the USA by the Smithsonian Institution Press)

9 Richard Werbner Tears of the dead: the social biography of an Afncan family (Published in the USA by the Smithsonian Institution Press and in Zimbabwe by Baobab Press)

10 Colin Murray Black Mountain: land, class and power in the eastern Orange Free State, 1880s to 1980s (Published in the USA by the Smithsonian Institution Press and in South Africa by Witwatersrand University Press)

$11 \mathrm{~J}$. S. Eades Strangers and traders: Yoruba migrants, markets and the state in northern Ghana (Published in the USA and Africa by Africa World Press)

12 Isaac Ncube Mazonde Ranching and enterpnse in eastern Botswana: a case study of black and white farmers.

13 Melissa Leach Rainforest relations: gender and resource use among the Mende of Gola, Sierra Leone (Published in the USA by the Smithsonian Institution Press)

14 Tom Forrest The advance of African capital: the growth of Nigerian private enterprise (Published in the USA by the University Press of Virginia and in Nigeria by Spectrum Books)

15 C. Bawa Yamba Permanent pilgrims: the role of pilgrimage in the lives of West African Muslims in Sudan (Published in the USA by the Smithsonian Institution Press)

16 Graham Furniss Poetry, prose and popular culture in Hausa (Published in the USA by the Smithsonian Institution Press)

\section{Editorial Consultants \\ Kofi Agawu Pierre Bonte \\ John Comaroff Johannes Fabian \\ Paulin Hountondji Ivan Karp}

Sally Falk Moore 


\title{
POETRY, PROSE AND POPULAR CULTURE IN HAUSA
}

\author{
GRAHAM FURNISS
}

EDINBURGH UNIVERSITY PRESS

for the International African Institute, London 


\title{
For Wendy, Eleanor, Jack and Katie, Dalhatu, Dauda, Omar and Dije
}

\author{
in memoriam \\ Ibrahim Yaro Yahaya
}

That's what we're looking for

the right words that people can make use of

Yazi Dogo

(C) Graham Furniss, 1996

Transferred to digital print 2009

Edinburgh University Press Ltd

22 George Square, Edinburgh

Reprinted 1997

Typeset in Linotronic Plantin

by Koinonia, Bury, and

Printed and bound in Great Britain by

CPI Antony Rowe, Chippenham and Eastbourne

A CIP record for this book is available from the British Library

ISBN 0748607862 